\title{
Mobbing of Working Students
}

\author{
Alessandra Rodrigues Jacoby ${ }^{1}$ \\ Faculdades Integradas de Taquara, Taquara-RS, Brazil \\ Janine Kieling Monteiro \\ Universidade do Vale do Rio dos Sinos, São Leopoldo-RS, Brazil
}

\begin{abstract}
Workplace mobbing has become a common topic. Taking into account the increasing reports of this act, this study was aimed at investigating the prevalence of mobbing in relation to university students who work and also ascertaining the most frequent biosociodemographic and work characteristics of the group of workers who were mobbed. The sample was composed of 457 working students living in the metropolitan area of Porto Alegre, in the state of Rio Grande do Sul, and usedas instruments a Biosociodemographic and Employment questionnaire and the Negative Acts Questionnaire (NAQ). It could be observed that $89.3 \%$ of the students had a mobbing score according to the NAQ - objective measure. As per the subjective measure, $11.2 \%$ of the participants stated to having beenmobbed. High rates of the practice of hostile acts in the workplace can be noted, but these are often viewed as mundane and normal acts in the workplace. In conclusion, it is necessary to seek alternatives in order to overcome this problem, which already affects a significant number of workers.
\end{abstract}

Keywords: mobbing, work, violence, health

\section{Assédio Moral em Estudantes Trabalhadores}

\begin{abstract}
Resumo: O assédio moral tornou-se uma discussão frequente no mundo do trabalho. Levando em consideração o aumento de relatos desta prática, o objetivo deste estudo foi investigar a prevalência de assédio moral em estudantes universitários que trabalham e averiguar quais são as características biosociodemográficas e laborais mais frequentes no grupo de trabalhadores que sofreram assédio moral. A amostra foi composta por 457 estudantes trabalhadores da região metropolitana de Porto Alegre/RS, utilizando como instrumentos um questionário Biosociodemográfico e Laboral e o Questionário de Atos Negativos (QAN). Constatou-se que $89,3 \%$ dos estudantes apresentaram escore de assédio moral de acordo com o QAN - medida objetiva. De acordo com a medida subjetiva, $11,2 \%$ dos participantes declararam ter sofrido assédio moral. Pode-se verificar altos índices da prática de atos hostis no trabalho, muitas vezes, vistos como atitudes corriqueiras e normais no ambiente laboral. Conclui-se que é necessário buscar alternativas para superar este problema, que já atinge uma parcela significativa de trabalhadores.
\end{abstract}

Palavras-chave: assédio moral, trabalho, violência, saúde

\section{Acoso Moral en Estudiantes Empleados}

\begin{abstract}
Resumen: Acoso moral se ha convertido en una discusión común en el mundo del trabajo. Teniendo en cuenta el aumento de las denuncias de esta práctica, un estudio cuantitativo se realizó para investigar la prevalencia de acoso moral en estudiantes universitarios trabajadores y verificar cuales son las características biosociodemográficas y laborales más frecuentes en el grupo de trabajadores víctimas de acoso moral. La muestra abarcó a 457 estudiantes que trabajan en el área metropolitana de Porto Alegre/RS, utilizando un cuestionario Biosociodemográfico y Laboral y el Negative Acts Questionnaire (QAN). Se encontró que el 89,3\% de los encuestados tenía una puntuación de acoso moral de acuerdo con la QAN - medición objetiva. De acuerdo con la medida subjetiva, el $11,2 \%$ de los participantes dijo haber experimentado acoso moral. Puede contener altos niveles de práctica de actos hostiles en el trabajo, a menudo visto como actitudes comunes y normales en el ambiente de trabajo. Así, llegamos a la conclusión de que es necesario buscar alternativas para superar este problema, que ya afecta una parte significativa de los trabajadores.
\end{abstract}

Palabras clave: asedio moral, trabajo, violencia, salud

In the current economic scenario, where competition is high and consumers become more demanding, both with regard to quality and cost, companies are increasingly seeking a differential in order to survive the pressure put by the market. Rezende (2006) states that this is a new era, in which individualism rules and the market chooses the profile of the workers who meet the day-to-day performance expectations: autonomous and flexible, capable, competitive, creative,

\footnotetext{
1 Correspondence address:

Alessandra Rodrigues Jacoby. Faculdades Integradas de Taquara. Av. Oscar Martins Rangel, 4500. Fogão Gaúcho. CEP 95600-000. Caixapostal: 84. Taquara-RS, Brazil. E-mail: ale@faccat.br
}

qualified and employable. Provocation, harassment and envy in the workplace become more common and the scary environment ends up occurring in organizations. Working in fear is part of the daily routine of many people (Ferreira, 2008).

Several studies have been carried out in relation to the workplace, the management styles of organizations and their impact on the mental health of workers (Amazarray, 2010; Pereira, 2011; Rigotto, Maciel, \& Borsoi, 2010; Soboll, 2008). Among the studies in this area, Freitas (2007) argues that mobbing occurs in the workplace, under institutional conditions and among the parties of this scenario. In this sense, organizations are not only the place where this happens, 
but also operationalize and take advantage of the mobbing, allowing managers to act in the facilities in different ways, to encourage, suppress or eliminate the psychological violence issue in the workplace (Eberle, Soboll, \& Cremasco, 2009).

\section{Workplace Violence}

Psychological violence is a subtle form of violence that often occurs silently and is not easily noted in the workplace (Amazarray, 2010; Araújo, Calgaro, Siqueira, \& Fernandes, 2010; Monteiro \& Machado, 2010). Behaviors like physical aggression, task intervention, threats, intimidation, discrimination, aggressive message, offensive, hostile behavior, isolation, harassment of groups, rape, blackmail, aggressive stance, rude gesture, provocation, yelling, deliberate silence, insinuation, swearing, among many others, are forms of workplace violence (Amazarray, 2010; Ferreira, 2008; Monteiro \& Machado, 2010).

For the Employment International Organization (EIO, 2002), workplace violence is marked by aggressive and abusive behaviors that may cause physical, psychological damage or discomfort in other people, whether they are or not intentional. Concerning psychological violence in the workplace, all workers are possible targets, with the aim to increase productivity and/or reinforce the submission to the boss. Psychological violence may be intentional and used as a management strategy, even though it can greatly affect the physical and psychological health of the workers (Monteiro \& Machado, 2010).

Workplace violence has been strengthened by the current management styles, in which perversity is the great premise, based on poor working conditions, the constant threat of unemployment or having their job outsourced, the requirement for constant updating and qualification of workers and the totalitarian ideologies that contribute to alienation (Barreto \&Venco, 2011; Martins, Moraes, \& Lima, 2010; Monteiro, 2010). It appears perverse because it leads workers to believe that, by being a model worker and "embracing" the company, there will be recognition and their desires will be fulfilled, which is not often the case (Monteiro \& Machado, 2010). Seeking to avoid such threats, workers need to show they are productive and competitive at any cost (Eberle, Soboll, \& Horst, 2010; Martins et al., 2010).

According to Ferreira (2008), violence cannot be seen as something that is natural for human beings, since this might reduce the fear and transformation that it causes. When hostile or violent behaviors of psychological nature become systematic and persistent acts, they can become mobbing (Eberle et al., 2010; Monteiro \& Machado, 2010).

\section{Mobbing}

Mobbing has been causing concern to workers, employees and also the scientific community. Authors who are devoting themselves to study this issue state that the term workplace mobbing is recent, although abuse and humiliation haveoccurred since ancient times (Barreto, 2003; Heloani, 2008; Jacoby, Falcke, Lahm, \& Nunes, 2009; Soboll, 2008).
But only in 1980, when it was identified as a highly destructive behavior in the workplace, mobbing became the object of study and systematic research (Barreto, 2003). In Brazil, mobbing started to be discussed and investigated in the year 2000 , but there is still a lack of integration among the practice areas and of a consensus between reality and theory, given that many cases which are described as workplace violence, for not being systematic, could fit into the concept of mobbing due to the magnitude of the violence experienced (Soboll, 2008).

There is no accurate definition for mobbing in the employment legislation but, in scientific literature, the issue is set out as an abusive and systematic conduct within organizations and occurs gradually. It consists of a series of humiliation, harassment and simultaneous aggression, aimed at emotionally disturbing the victims, causing them fear of losing their jobs and even putting their lives at risk (Barreto, 2003; Barreto \& Venco, 2011; Hirigoyen, 2005).

In mobbing, there is a more subtle or less obvious context of discrimination (Hirigoyen, 2005). It may also be caused by the non-acceptance of a difference that exists in the working group. The differences may be represented both by different workloads and the professional qualities that pose a threat to someone. The author of the mobbing act shows difficulty in accepting someone who is different from the group. Another context that may increase the chances of mobbing to occur is a poorly conducted power game within the organizations, leading to a hostile and disturbing environment (Silva, Oliveira, \& Zambroni-de-Souza, 2011). Workers end up experiencing fear in an environment full of threats: fear of being humiliated or dismissed, of not meeting the requirements expected of them (Eberle et al., 2009).

Therefore, many organizations end up being complacent with mobbing, leaving the power in the hands of an enterprising manager who seeks results without worrying about aggressive behaviors in a competitive market (Peli $\&$ Teixeira, 2006). Managers seek, therefore, maximum performance from workers, using mobbing as a tool to reach their goals (Silva et al., 2011; Soboll, 2008).

The duration of mobbing is, on average, three years (Hirigoyen, 2005) and it usually emotionally disturbs the victim of the aggressions, bringing consequences to the various areas of the victim's life. However, there is no consensus in relation to the frequency and duration of the negative acts, although almost all the authors state that the violence is required to take place in a systematic way for a long period of time in order to be considered mobbing (Soboll, 2008).

Reports of mobbing situations experienced by participants of the study developed by Jacoby et al. (2009) show the progressive deterioration of the workplace, reflecting on the personal and financial life of workers, as well as on their physical and psychological health. The victims of mobbingwho participated in this study had characteristics such as strong determination, knowledge, competence, honesty, dynamism, ethics and attitudes that granted them trust and attention in their workplace. This attention may have been one of the reasons they were chosen as victims, 
since envy appeared as a possible cause for bullies to try to disturb their victims and remove them from the workplace.

Amazarray (2010) studied 598 banking workers employed by institutions located in Porto Alegre and Metropolitan Area and found that $88.6 \%$ of the respondents had experiencedmobbing. Among the cases of work-related illnesses, there were musculoskeletal disorders, stress, depression, anxiety/panic, back problems, gastritis/ulcer, hypertension or cardiovascular diseases, psychosomatic illnesses, headaches, vision problems and others.

In a research carried out in São Paulo involving 2072 men and women, Barreto (2003) found that, among the men who felt mobbed in the workplace, all of them had already considered committing suicide and $18.3 \%$ had tried it. In addition, $63 \%$ had started to drink excessively. With respect to the women, $16.2 \%$ of the mobbing victims reported having suicidal thoughts, but none of them had actually tried it. From the total of the female sample, $5 \%$ became alcoholic and $100 \%$ started to have crying episodes. These data show that men and women have different ways of expressing their emotions and frustrations when facingmobbing, but both genders referred to negative emotional consequences in their lives.

The connection among the physical, psychological, social and economic consequences resulting from mobbing can be clearly noted, once a real vicious cycle is created, in which a negative self-image may cause the victim to somatize reactions, thus affecting their performance and consequently their income, since they will have medical expenses, the need for psychological treatment and expenditure with lawyers (Jacoby et al., 2009). According to Hirigoyen (2005), the situation is aggravated in many cases because the mobbed persons end up leaving the job (being fired or resigning) and take with them the trauma of the violence experienced, which often becomes an obstacle in the search for a new job. Not having a good self-image, the persons feel unable to gather sufficient energy to invest in the search for a new job.

It is believed that there is a difficulty in distinguishing mobbing since it involves a silent, subtle and discreet violence. So discreet that it often makes the victims think whether they are not really responsible for what is happening to them and also doubt about their own mental health. It is important that organizations set the example through transparent actions, conscientious professionals and management styles that do not accept to contravene the ethics and morals. Solid and healthy organizations have no place for mobbing (Hirigoyen, 2005). But, firstly, it is necessary to act in an ethical manner and not only verbally express their values.

Based on the above, this study was aimed at investigating the prevalence of mobbing in relation to university students of a private institution located in the metropolitan area of Porto Alegre, in the state of Rio Grande do Sul, who work, and also ascertaining the most frequent biosociodemographic and work characteristics of the group of workers who were mobbed.The choice of this group of workers was made taking into account that, the higher the educational level of the worker, the higher their expectation concerning the manner in which they will be treated at work, their sensitivity to acts against the dignity and their willingness to report this view through questionnaires (Health and Safety Authority [HSA], 2001). Furthermore, only one study developed in Brazil was found (Trombetta, 2005) concerning university students and mobbing.

\section{Method}

\section{Participants}

Four hundred and fifty seven working students enrolled in a private university in 2011 located in the metropolitan area of Porto Alegre/RS, from both genders and employed in companies of different areas, participated in this study. The sample calculation, with reliability rate of $95 \%$ and error rate of $5 \%$, predicted 362 participants, taking into account the population of 6,000 students in the abovementioned university, whether or not they were workers, in order to detect small to medium effect sizes, considering the significance level of $p=.05$ and chance of not making an error $\beta$ of $90 \%$, in most designs. The inclusion criteria considered the fact that the students had been working for at least six months.

\section{Instruments}

Biosociodemographic and Employment Questionnaire. For this study, a self-administered instrument composed of biosociodemographic and employment questions was developed, aiming to obtain information about age, gender, marital status, educational level, number of children, company area which they work in, role performed, time of work, occupational accident/illness history and others.

Negative Acts Questionnaire (NAQ). This self-applied instrument has been largely used in Europe, where it is known as Negative Acts Questionnaire (NAQ). It was developed in Norway and revised by Einarsen and Raknes (Einarsen \& Hoel, 2001). This instrument was translated and validated in Brazil by Maciel and Gonçalves (2008). The first part of the instrument assesses the exposure to negative and potentially mobbingacts during the last six months on a five-point Likert scale (never, sometimes, monthly, weekly and daily). They are descriptions of negative acts that do not mention the term mobbing and refer to direct (verbal aggression, intimidation, among others) and indirect behaviors (social isolation, pressure and others). In the second part, a definition of workplace mobbingis proposed and respondents are required to state if they were exposed to it in the last six months, followed by questions about the duration and features of the event. Then, two questions are added to investigate if the participants had already mobbed anyone in the workplace in the last six months and in the last five years, and three other open questions related to the workplace environment.

Studies with different samples, according to Einarsen and Hoel (2001), show high internal consistency of the 
instrument, with Cronbach's Alpha scores ranging from .83 to .92. Recent research (Maciel \& Gonçalves, 2008) found an Alpha of .90 for the reduced version containing 22 items. In the present study, the long version with 29 items was used and the Cronbach's Alpha coefficient found was .92.

From the NAQ, a dichotomous variable was developed, which constitutes an objective measure of mobbing: the Frequent Mobbing (if the participants scored $5=$ daily or $4=$ weekly in at least one of the items) and the Eventual Mobbing (if they scored $3=$ monthly or 2 =sometimes in at least one of the items). Those who scored 1 (=never) in all of the items in the scale had not been victims of workplace mobbing, according to this criterion. Also, the variable Perceived Mobbing was created and this was considered a subjective measure, since it results from the worker's perception in relation to the definition of workplace mobbing. This categorical variable was classified as frequent (if the participants answered several times a week or almost daily) and eventual (if they scored very rarely, sometimes or several times a month) (Amazarray, 2010).

\section{Procedure}

Data collection. Data collection was carried out inside the classrooms of the university, collectively, on paper, during classes, in the period between August and October 2011, with students from Administration, Accounting and Psychology courses. The students weretaking between the first and the last year of study. Before the administration, the students received information about the study (purpose, ways of answering the instruments) and read and signed the Informed Consent Form. The instruments were administered only to students who were employed and the average duration for the completion of the questionnaires was 15 minutes. Before the collection, a pilot study was undertaken to verify the time required to answer the set of instruments.

Data analysis. The results of the instruments were entered into a database for later analysis. In order to investigate the presence/absence of workplace mobbing based on the NAQ, the most common frequencies of negative acts of workers who identified themselves as victims, witnesses and offenders at some work event, as well as other characteristics of the event, were listed. The frequencies and percentages of each nominal variable were calculated. In addition, the test of association between Chi-square variables was used to investigate possible associations between some sociodemographic and employment characteristics (gender, sexual orientation, race and organizational level) and the mobbing experience.

\section{Ethical Considerations}

The study was approved by the Research Ethics Committee of the Universidade do Vale do Rio dos Sinos (Registration 050/2011, approved in May 19, 2011). The participants signed an Informed Consent Form, in which the preservation of their identity and confidentiality in relation to the information provided were assured.

\section{Results}

Concerning the participants' profile, 69.1\% were women and $30.9 \%$ men. The age ranged between 17 and $64(M=26.02 ; S D=8.02)$. Due to the fact that they were college students, $66.4 \%$ had completed high school, $31 \%$ had completed higher education and were attending another graduation course and $2.6 \%$ had completed a postgraduate course. With regard to their marital status, $68.7 \%$ were single and $28.7 \%$ married. As for sexual orientation, $98.6 \%$ of the participants answered they were heterosexual. With respect to the participants' race-ethnic background, which was categorized under the criterion "race", according to the Brazilian Institute of Geography and Statistics (IBGE), the following answers were given: $95.8 \%$ Caucasian, 3\% mulatto and $1.2 \%$ black. Concerning the question related to religion, $71.2 \%$ stated to be catholic, $9.7 \%$ evangelic, $9.7 \%$ protestant/Lutheran, $4.2 \%$ spiritualists, while $3.7 \%$ did not follow a religion.

Regarding the organizational status, $59.1 \%$ worked at operational level, $15.5 \%$ were middle management, $8.8 \%$ senior management and $16.6 \%$ answered they belonged to another hierarchic level. As for the role performed, most of them $(22.1 \%)$ worked as administration assistants; they werefollowed by senior management positions (13.8\%), commercial $(12.9 \%)$ and financial $(9.8 \%)$ positions and teachers $(6.6 \%)$.

Most of them worked day shifts (92.4\%), few of them night shifts $(0.4 \%)$, some of them in both shifts $(5.4 \%)$, and some did not answer (1.8\%). The weekly working hours was up to 30 hours for $15.9 \%$ of the participants, from 31 to 40 hours for $28.8 \%$, from 40 to 44 for $42.2 \%$, and over 45 hours for $13.1 \%$. The period of time working for the company ranged from six months to 39 years $(M=4.27 ; S D=5.05)$ and the period of time in the current position ranged from one month to 27 years $(M=3.20, S D=3.69)$.

Few workers reported a workplace accident or illness (7.6\%), ranging from: travelling accident, finger cut, back problems, stress crisis, tendinitis, allergy and others. In relation to the support received as a result of a workplace adverse situation, $97.6 \%$ of the participants reported seeking some kind of assistance, among them: $35.1 \%$ seek the human resources department or a service specialized in occupational health and safety, $33.3 \%$ seek the family's support, $13 \%$ seek management, $5.6 \%$ seek the union and the others seek friends, healthcare services and local employment office.

If mobbing is considered based on the presence of the negative acts described in the NAQ, 89.3\% $(n=408)$ of the participants had experienced some kind of workplace mobbing in the last six months. Table 1 shows the frequency of negative acts according to some biosociodemographic data. All the participants who stated to be homosexual or black reported to have been victims of workplace violence. 
Table 1

Frequency of Mobbing According to Some Biosociodemographic Data

\begin{tabular}{|c|c|c|c|c|c|}
\hline Variables & $\begin{array}{c}\text { Have been victims of } \\
\text { mobbing }\end{array}$ & $\%$ & $\begin{array}{l}\text { Have not been victims of } \\
\text { mobbing }\end{array}$ & $\%$ & $n$ \\
\hline \multicolumn{6}{|l|}{ Gender } \\
\hline Female & 280 & 88.6 & 36 & 11.4 & 316 \\
\hline Male & 128 & 90.8 & 13 & 9.2 & 151 \\
\hline \multicolumn{6}{|l|}{ Age } \\
\hline $17-26$ & 220 & 89.8 & 25 & 10.2 & 245 \\
\hline $27-36$ & 78 & 85.7 & 13 & 14.3 & 91 \\
\hline $37-46$ & 22 & 95.7 & 01 & 4.3 & 23 \\
\hline Over 46 & 13 & 86.7 & 02 & 13.2 & 15 \\
\hline \multicolumn{6}{|l|}{ Sexual Orientation } \\
\hline Heterosexual & 386 & 89.6 & 45 & 10.4 & 431 \\
\hline Homosexual & 06 & 100 & 00 & 0 & 06 \\
\hline \multicolumn{6}{|l|}{ Marital Status } \\
\hline Single & 278 & 89.4 & 33 & 10.6 & 311 \\
\hline Married & 115 & 88.5 & 15 & 11.5 & 130 \\
\hline Divorced & 11 & 91.7 & 01 & 8.3 & 12 \\
\hline \multicolumn{6}{|l|}{ Race } \\
\hline Caucasian & 347 & 89.2 & 42 & 10.8 & 389 \\
\hline Black & 05 & 100 & 00 & 0 & 05 \\
\hline Brown & 11 & 91.7 & 01 & 10.6 & 12 \\
\hline \multicolumn{6}{|l|}{ Sector } \\
\hline Private & 314 & 90.2 & 34 & 9.8 & 348 \\
\hline Public & 81 & 88 & 11 & 12 & 92 \\
\hline \multicolumn{6}{|l|}{ Organizational level } \\
\hline Operational & 237 & 87.8 & 33 & 12.2 & 270 \\
\hline Middle Management & 68 & 95.8 & 03 & 4.2 & 71 \\
\hline Senior Management & 35 & 87.5 & 05 & 12.5 & 40 \\
\hline
\end{tabular}

Middle management is shown to be the organizational level with the highest rate of negative acts experience (95.8\%).

Using the distinction between frequent mobbing and eventual mobbing through the objective measure, mobbing was frequent for $22.5 \%$ of the cases and eventual for $66.7 \%$. In relation to gender, $27 \%$ of the men and $20.6 \%$ of the women were victims of frequent mobbing. Concerning eventual mobbing, $68 \%$ of the men and $63.8 \%$ of the women experienced negative acts. The age group with the highest rate of eventual negative acts was between 37 and 46 years (78.3\%), and of frequent negative acts from 17 to 23 years old (23.7\%). With respect to the question about the period of time the participants worked in the company, there was frequent mobbing in relation to the participants working in the company between one and two years $(23.3 \%)$, up to one year $(22.3 \%)$, and more than five years $(20.4 \%)$. Concerning eventual mobbing, $27 \%$ of the participants had been working for the company for more than five years and $24 \%$ for up to one year. When comparing gender, age, race, sexual orientation and period of time working in the company, there were no significant differences $(p<.05)$ with regard to the prevalence of mobbing.

According to the subjective measure, in which the participants answered the questions related to mobbing after a conceptual definition, only $10.5 \%$ stated to have been victims of mobbing in the last six months, $9.2 \%$ considered themselves victims of eventual mobbing and $0.2 \%$ of frequent mobbing. Therefore, based on the perceived mobbing criterion, it occurs less frequently, and $89.3 \%$ of the participants did not consider themselves victims of this kind of violence, as shown in Table 2.

Concerning the data related to witnessing mobbing, $34.1 \%$ of the participants stated to have witnessed abusive acts in the workplace in the last six months, and $37.6 \%$ in the last five years. On the question related to carrying out abusive acts, $5.5 \%$ of the sample admitted to have mobbed other people in the last six months and $10.7 \%$ in the last five years.

Among the workers who gave affirmative answers to the perceived mobbing, $37.8 \%$ reported that the negative acts had started in the last six months, 33.6\% between six and 12 months and $20 \%$ between one and two years. The main source perpetrator, as reported by the victims, was their superior $(39.6 \%)$, followed by their superior and colleagues $(24.2 \%)$ and only colleagues $(14.6 \%)$. The clients appeared as those who least mobbed others $(2.1 \%)$. Men appeared as the main perpetrators $(49 \%)$, followed by men and women $(28.6 \%)$ and, finally, only women $(22.4 \%)$. In relation to the number 
Table 2

Frequencies and Percentages of Workplace Mobbing According to Different Measures

\begin{tabular}{|c|c|c|c|}
\hline Measure & $f$ & $\%$ & $N$ \\
\hline \multicolumn{4}{|l|}{ Objective (NAQ) } \\
\hline Frequent mobbing in the last 6 months & 305 & 22.5 & 457 \\
\hline Eventual mobbing in the last 6 months & 103 & 66.7 & 457 \\
\hline \multicolumn{4}{|l|}{ Subjective (perceived mobbing) } \\
\hline Have frequently been mobbed in the last 6 months & 1 & 0.2 & 457 \\
\hline Have eventually been mobbedin the last 6 months & 48 & 10.5 & 457 \\
\hline Have witnessed mobbing in the last 6 months & 154 & 34.1 & 452 \\
\hline Have mobbedin the last 6 months & 25 & 5.5 & 451 \\
\hline Have been mobbedin the last 5 years & 112 & 24.9 & 450 \\
\hline Have witnessed mobbing in the last 5 years & 172 & 37.6 & 450 \\
\hline Have mobbedin the last 5 years & 49 & 10.7 & 451 \\
\hline
\end{tabular}

Note. There was a difference in relation to the $N$ because some students did not answer all the questions.

of people who were victims of abusive acts in the workplace, most of the participants reported to have experienced violence together with other colleagues $(n=41,83.7 \%)$ and only eight participants reported to have been mobbed alone.

In an attempt to verify if mobbing caused health issues, it was asked if the worker considered that health problems were a consequence of mobbing. Of the 51 participants who described themselves as victims, 37 answered the question. Among the most common psychological diseases, the ones mentioned were: stress $(19 \%)$, depression $(8 \%)$, demotivation $(5 \%)$, migraine (8\%), eating disorders (14\%) and insomnia (11\%).

\section{Discussion}

The objective measure provided access to the number of workers exposed, eventually or frequently, to typical mobbing situations and to negative acts more often used by perpetrators. The subjective measure permitted knowing how many participants felt mobbed, based on the victims' perception of the subject, and what people were involved in the violence.

Regarding the prevalence of mobbing found in this study sample, the percentages of both objective and subjective variables, were higher in comparison to other studies worldwide, which also used the NAQ. Zapf, Einarsen, Hoel and Vartia (2003) mentioned the prevalence found in studies from 11 countries located in the South and North of Europe, in which the objective measure for frequent mobbing ranged from $3 \%$ to $7 \%$, and the perceived mobbing from $1 \%$ to $4 \%$. Agervold (2007), in Denmark, through the objective measure, found $4.7 \%$ for frequent mobbing and $1 \%$ for perceived mobbing. In Italy, Giorgi (2008) identified $27.8 \%$ of workers in the frequent mobbing category (objective measure). In a sample in the United Kingdom, Einarsen, Hoel and Notelaers (2009) found the prevalence of $10.6 \%$ of the respondents who felt mobbed. Verdasca (2010), in his study involving bank clerks in Portugal, found the prevalence of frequent mobbing of $39.4 \%$ through the objective measure and $5.9 \%$ in the subjective one.

In Brazil, there are few studies using the NAQ, such as the study carried out by Maciel Gonçalves (2008), involving bank workers and from various sectors, in which the prevalence of mobbing, both frequent and eventual, was of $26 \%$ through the objective measure and $15 \%$ through the subjective one. Also in a research involving bank clerks, Amazarray (2010) found $88.6 \%$ of workers who had experienced both frequent and eventual mobbing through the objective measure, and 35.1\% through the subjective one. Based on the studies mentioned, the mobbing rates in the sample studied were high, with a result very close to Amazarray's study and different from the Europeans', in which the scores were very low.

Although the prevalence of mobbing is different in various countries, a fact that drew attention in all the studies mentioned was the variation found between the objective and subjective measures concerning the frequency of mobbing (Agervold, 2007; Amazarray, 2010; Einarsen et al., 2009; Giorgi, 2008; Maciel \& Gonçalves, 2008; Verdasca, 2010; Zapf et al., 2003). In the present study, it was possible to confirm this information and the percentage of workers who were classified as victims of mobbing was higher than the workers who perceived themselves as victims.

Several variables can be the cause of this discrepancy. One of the main ones is probably the trivialization of violence within the modern workplace, often being viewed as belonging to this environment. Some elements that may be related to the fact that workplace mobbingis being viewed as natural include: poor working conditions, constant threats of unemployment or of having their job outsourced, lack of information, disqualification of the work performed and styles of management that encourage competition and individualism (Barreto \& Venco, 2011; Martins et al., 2010; Monteiro, 2010; Monteiro \& Machado, 2010).

The lack of information about what workplace mobbingwould be is another relevant aspect, since many workers are unaware that some subtle behaviors or even management strategies are acts of psychological workplace violence and mobbing. Although many workers realize they are being victims of violence due to their being exposed to negative acts, they avoid to be seen as such, because otherwise 
they could have their image associated to weakness, passivity and inferior position (Amazarray, 2010).

Another aspect to be considered is that many mobbing victims will see themselves as such only after a certain period of time, since the acts are often not seen as abusive and happen subtly and gradually (Barreto, 2003; Hirigoyen, 2005). The data presented in this study reinforce this statement and show that those workers who consider themselves as victims of mobbing had been submitted to mobbing for more than six months $(62.2 \%)$.

Regarding biosociodemographic data, such as gender, age, marital status, sector and organizational level, although a difference had been found between the percentages of the presence of mobbing showed by the groups, these data did not have a significant association, which was investigated through the Chi-square test. In any event, the data relating to the sexual orientation and race continued to draw attention and deserve to be investigated in more depth in future studies. Although few participants stated to be black or homosexual, all of those who made this statement had gone through violent situations.

As for the type of relationship between the victim and the bully, it could be noted that most of them were abused by their immediate superior. However, part of them claimed to have been submitted to aggressive acts from their superior and colleagues or only colleagues, confirming the information presented in the literature, which states that the mobbing directed to subordinates by their superior is the most frequent one (Hirigoyen, 2005; Jacoby et al., 2009; Verdasca, 2010).

It can be also noted that there is a trend of group mobbing since, besides being victims, many workers witnessed situations of violence, once again showing the likely organizational strategy (of increased production) and the fact that the acts have not always been seen as abusive. In addition, victims often do not view themselves as such, due to embarrassment and fear of losing thestatus within the company. Therefore, mobbing is a kind of violence that can be experienced or witnessed at the same time. However, there was a low rate of people who see themselves as those carrying out abusive acts and this is probably due to the reasons previously mentioned.

\section{Final Considerations}

Based on the information collected in the present study, there were high rates of psychological violence in organizations, often seen as mundane and ordinary acts in the workplace, which are part of management strategies and global policies. This is, therefore, a collective issue in the studied area, since it affects a significant portion of employed university students. However, these data should be carefully considered because they cannot be generalized to other student groups who are working. In the studied sample, the level of education may have contributed to this result, given that the higher the educational level of the worker, the higher their expectation concerning the manner in which they will be treated at work, their sensitivity to acts against the dignity and their willingness to report this view through questionnaires (HAS, 2001).
The use of the NAQ allowed the comparison of mobbing rates with studies undertaken in other countries and it also allowed identifyingthe mobbing victims without the need for them to recognize themselves as such. On the other hand, the classification of eventual mobbing defined by the NAQ (to have experienced at least one negative act - monthly or sometimes - in the last six months) can be questioned, since it may indicate psychological workplace violence and not mobbing, taking into account thatmobbing involves an abusive and systematic conduct.

Since this study was focused on investigating the prevalence of mobbing in relation to university students from a certain area who work, the research achieved its objective. However, these results should be carefully considered and not generalized to the working student population; besides, other studies are required to identifymobbing more broadly. Among these, a research of all educational levels is suggested, maybe trying to focus more on the profile of perpetrators and the management styles that encourage mobbing, thus expanding the understanding of this complex subject. In addition, it is suggested that further studies investigate cases that have been reported and in which the mobbing act has been proved, in order to have material that is not only based on the perception of the victims. A follow-up of these cases can be elaborated in the workplace to ascertain the degree of influence that the profile of the victim and management style had on it. It would also be interesting to carry out studies within companies that are identified as promoting mobbing, taking into account their management style, as well as to develop and monitor an intervention program to evaluate its impact.

Prevention would be a solution to fight against this kind of violence, working within families, schools, workplace organizations in order to provide information to citizens, so that abusive acts are not covered up and, even worse, promoted within workplaces. Healthcare professionals are essential both in the prevention process and management of mobbing cases, acting as mediators between workers within institutions, and in the development of studies in order to identify and inform abusive acts when they start, seeking their interruption. However, according to the data collected, the workers do not often seek specialized services for support. It is necessary to strengthen and promote these services within companies, and it is crucial that healthcare professionals have greater knowledge about the subject and the reality of organizations in order to effectively treat workplace-related suffering.

\section{References}

Agervold, M. (2007). Mobbing at work: A discussion of definitions and prevalence, based on an empirical study. Scandinavian Journal of Psychology, 48(2), 161-172. doi:10.1111/j.1467-9450.2007.00585.x

Amazarray, M. R.(2010). Violência psicológica e assédio moral no trabalho enquanto expressões de estratégia de gestão. (Unpublished doctoral dissertation). Universidade Federal do Rio Grande do Sul, Porto Alegre, RS. 
Araújo, J. N. G., Calgaro, J. C. C., Siqueira, M. V. S., \& Fernandes, M. I. A. (2010). Abordagem socioclínica da violência no trabalho. In A. M. Mendes (Org.), Violência no trabalho: Perspectivas da psicodinâmica, da ergonomia e da sociologia clínica (pp. 41-60). São Paulo, SP: Universidade Presbiteriana Mackenzie.

Barreto, M. M. S. (2003). Violência, saúde e trabalho: Uma jornada de humilhações. São Paulo, SP: EDUC.

Barreto, M., \& Venco, S. (2011). Da violência ao suicídio. In M. Barreto, N. B. Netto, \& L. B. Pereira (Orgs.), Do assédio moral à morte de si: Significados sociais do suicídio no trabalho (pp. 221-248). São Paulo, SP: Matsunaga.

Eberle, A. D., Soboll, L. A. P., \& Cremasco, M. V. F. (2009). Compreensões sobre o assédio moral a partir da psicodinâmica do trabalho. In L. A. P. Soboll, \& T. C. Gosdal (Orgs.), Assédio moral, interpessoal e organizacional: Um enfoque multidisciplinar (pp. 105-138). São Paulo, SP: LTr.

Eberle, A. D., Soboll, L. A. P., \& Horst, A. C. (2010). Avaliação comparativa de resultados e assédio moral organizacional: Concorrência generalizada, individualismo e adoecimento no trabalho. In A. M. Mendes, A. R. C. Merlo, C. F. Morrone, \& E. P. Facas (Orgs.), Psicodinâmica e clínica do trabalho: Temas, interfaces e casos brasileiros (pp. 519-534). Curitiba, PR: Juruá.

Einarsen, S., \& Hoel, H. (2001). The Negative Acts Questionnaire: Development, validation and revision of a measure of mobbing at work. Paper presented at the 10th European Congress on Work and Organizational Psychology, Prague, Czech Republic.

Einarsen, S., Hoel, H., \& Notelaers, G. (2009). Measuring exposure to mobbing and harassment at work: Validity, factor structure and psychometric properties of the Negative Acts Questionnaire-Revised. Work \& Stress, 23(1), 24-44. doi:10.1080/02678370902815673

Ferreira, J. B. (2008). Violência e assédio moral no trabalho: Patologias da solidão e do silêncio. In L. A. P. Soboll (Org.), Violência psicológica e assédio moral no trabalho: Pesquisas brasileiras (pp. 104-134). São Paulo, SP: Casa do Psicólogo.

Freitas, M. E. (2007). Quem paga a conta do assédio moral no trabalho? RAE-Eletrônica, 6(1). Retrieved from http:// rae.fgv.br/rae-eletronica/vol6-num1-2007/quem-pagaconta-assedio-moral-no-trabalho

Giorgi, G. (2008, October/December). The Negative Acts Questionnaire revised (NAQ-R) in Italy. Prevention Today, pp. 71-86.

Heloani, J. R. (2008). Contribuições da psicologia do trabalho em casos de assédio moral. In L. A. P. Soboll (Org.), Violência psicológica e assédio moral no trabalho: Pesquisas brasileiras (pp. 95-104). São Paulo, SP: Casa do Psicólogo.

Hirigoyen, M. F. (2005). Assédio moral: A violência perversa no cotidiano. Rio de Janeiro, RJ: Bertrand Brasil.
Health and Safety Authority. (2001). Report of the task force on the prevention of workplace mobbing: Dignity at work - the challenge of workplace mobbing. Dublin, Irish: The Stationary Office. Retrieved from http://www.entemp.ie/ publications/employment/2005/mobbingtaskforce.pdf

Jacoby, A. R., Falcke, D., Lahm, C. R., \& Nunes, G. J. (2009). Assédio moral: Uma guerra invisível no contexto empresarial. Revista Mal-Estar e Subjetividade, 9(2), 619-645.

Maciel, R. H., \& Gonçalves, R. C. (2008). Pesquisando o assédio moral: A questão do método e a validação do Negative Acts Questionnary (NAQ) para o Brasil. In L. A. P. Soboll (Org.), Violência psicológica e assédio moral no trabalho: Pesquisas brasileiras (pp. 167-185). São Paulo, SP: Casa do Psicólogo.

Martins, S. R., Moraes, R. D., \& Lima, S. C. C. (2010). Sofrimento, defesa e patologia: O olhar da psicodinâmica sobre a violência no trabalho. In A. M. Mendes (Org.), Violência no trabalho: Perspectivas da psicodinâmica, da ergonomia e da sociologia clínica (pp. 19-39). São Paulo, SP: Universidade Presbiteriana Mackenzie.

Monteiro, J. K. (2010). Organização do trabalho e sofrimento psíquico de trabalhadores da saúde. In A. M. Mendes, A. R. C. Merlo, C. F. Morrone, \& E. P. Facas (Orgs.), Psicodinâmica e clínica do trabalho: Temas, interfaces e casos brasileiros (pp. 335-346). Curitiba, PR: Juruá.

Monteiro, J. K., \& Machado, C. (2010). Violência no trabalho em um hospital público. In A. M. Mendes (Org.), Violência no trabalho: Perspectivas da psicodinâmica, da ergonomia e da sociologia clínica (pp. 139-154). São Paulo, SP: Universidade Presbiteriana Mackenzie.

Organización Internacional Del Trabajo. (2002). El trabajo decente es fundamental para elprogreso social. Ginebra: OIT. Retrieved from http://www.anep.or.cr/article/ el-trabajo-decente-es-fundamental-para-el-progreso/

Peli, P., \& Teixeira, P. (2006). Assédio moral: Uma responsabilidade corporativa. São Paulo, SP: Ícone.

Pereira, L. B. (2011). O mundo do trabalho e as questões éticas que envolvem o adoecer e morrer dos trabalhadores. In M. Barreto, N. B. Netto, \& L. B. Pereira (Orgs.), Do assédio moral à morte: Significados sociais do suicídio no trabalho (pp. 67-79). São Paulo, SP: Matsunaga.

Rezende, L. O. (2006). A deteriorização das relações de poder dentro do organismo empresarial: Uma análise do assédio moral no contrato de trabalho (Unpublished master's thesis). Universidade Federal do Paraná, Curitiba, PR.

Rigotto, R. M., Maciel, R. H., \& Borsoi, I. C. F. (2010). Produtividade, pressão e humilhação no trabalho: Os trabalhadores e as novas fábricas de calçados no Ceará. Revista Brasileira de Saúde Ocupacional, 35(122), 217-228. doi:10.1590/S0303-76572010000200005

Silva, E. F., Oliveira, K. K. M., \& Zambroni-de-Souza, P. C. (2011). Saúde mental do trabalhador: O assédio moral praticado contra trabalhadores com LER/DORT. Revista Brasileira de Saúde Ocupacional, 36(123), 56-70. doi:10.1590/S0303-76572011000100006 
Soboll, L. A. P. (2008). Assédio moral no Brasil: A aplicação conceitual e suas repercussões. In L. A. P. Soboll (Org.), Violência psicológica e assédio moral no trabalho: Pesquisas brasileiras (pp. 23-55). São Paulo, SP: Casa do Psicólogo.

Trombetta, T. (2005). Características do assédio moral a alunos-trabalhadores nos seus locais de trabalho (Unpublished master's thesis). Universidade Federal de Santa Catarina, Florianópolis, SC.

Verdasca, A. T. (2010). Assédio moral no local de trabalho: $O$ caso do sector bancário português (Unpublished doctoral dissertation). Universidade Técnica de Lisboa, Lisboa, Portugal.

Zapf, D., Einarsen, S., Hoel, H., \&Vartia, M. (2003). Empirical findings on mobbing in the workplace. In S. Einarsen, H. Hoel, D. Zapf, \& C. Cooper, Mobbing and emotional abuse in the workplace: International perspectives in research and practice (pp. 103-126). London, England: Taylor \& Francis.

Alessandra Rodrigues Jacoby is a Professor at the Faculdades Integradas de Taquara.

Janine Kieling Monteiro is a Professor of the Universidade do Vale do Rio dos Sinos.

Received: Jul. $2^{\text {nd }}, 2012$

$1^{s t}$ Revision: Aug. $14^{\text {th }}, 2013$

$2^{\text {nd }}$ Revision: Sep. $28^{\text {th }}, 2013$

Approved: Oct. 28 ${ }^{\text {th }}, 2013$

How to cite this article:

Jacoby, A. R., \& Monteiro, J. K. (2014). Mobbing of working students. Paidéia (Ribeirão Preto), 24(57),39-47. doi:10.1590/1982-43272457201406 


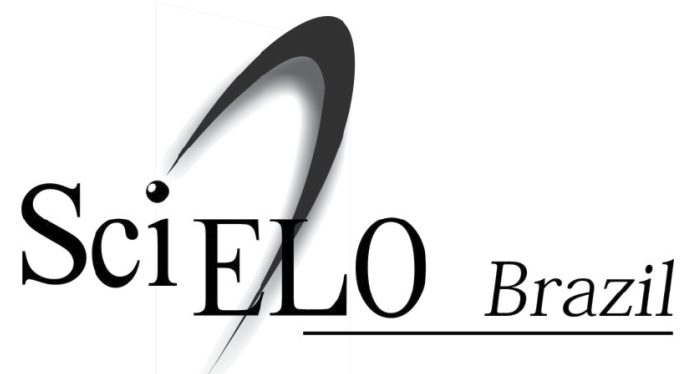

Paidéia (Ribeirão Preto) is a four-monthly publication available in full-text in the Scientific Electronic Library Online - SciELO.

The SciELO interface provides easy access to the tables of content and to the full-text articles.

The SciELO interface also provides the retrieval of articles by the author's name, the words from title, abstract and descriptors, in addition to providing bibliometric indicators and consultation indicators.

The articles are enriched with connections to the LILACS, MEDLINE and PubMed databases.

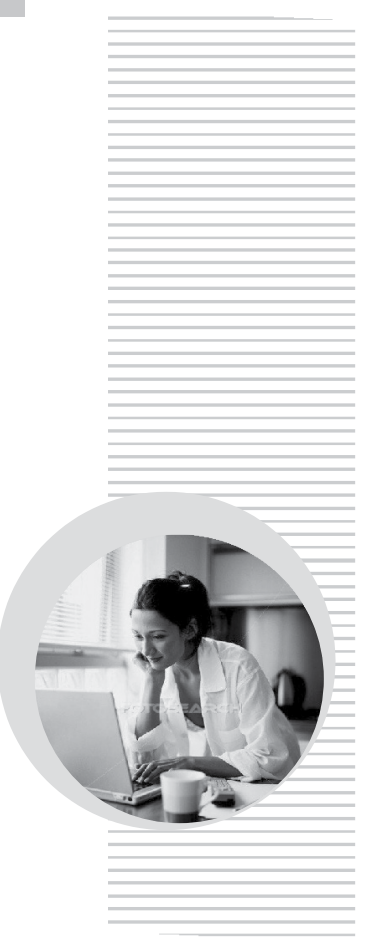

Paidéia (Ribeirão Preto) is a part of SciELO Brazil:

\section{www.scielo.br/paideia}

The SciELO interface provides access to a network of SciELO websites, gathering the major scientific journals of Latin America, Caribbean, Spain, Portugal and South Africa:

\section{www.scielo.org}

The electronic library is a project developed by the São Paulo Research Foundation (FAPESP), in partnership with the Latin American and Caribbean Center on Health Sciences Information (BIREME) and the National Council for Scientific and Technological Development (CNPq). 